\title{
Factors Affecting Honey Marketed Surplus of Beekeepers in Gera District of Oromia State, Ethiopia
}

\author{
Ayantu Arage Desalegn \\ Department of Agribusiness and Value Chain Management, Ambo University, Ethiopia. P.O.box 2017 Ambo \\ Mengistu Ketema Aredo \\ School of Agricultural Economics and Agribusiness, Haramaya University, Haramaya, Ethiopia. P.O.box 138 \\ Dire dawa, Ethiopia \\ Adeba Gemechu Gobena \\ Department of Agricultural Economics, Jimma University, Jimma, Ethiopia. P.O.box 307 Jimma Ethiopia
}

The authors received no direct funding for this research.

\begin{abstract}
Ethiopia has huge potential for beekeeping because of its endowment with diversity in climate and vegetation resources that potentially favor beekeeping. The gap in honey marketing is the main problem though Gera district is known for its high production of honey. Thus, this research attempted to analyze determinants of honey marketed surplus in Gera district of Oromia regional state. Multi stage sampling procedure was employed to draw sample of 139 honey producers. Descriptive statistics was used for characterizing farmers and econometrics analysis was used for identifying factors affecting honey marketed surplus. The two-stage least square regression model results showed that quantity of honey produced, family size, type of beehive used, beekeeping experience, distance to nearest market, frequency of extension contact and sex of the house hold head significantly affected honey marketed surplus. The study findings suggest that improving the input supply system, improving beekeeper's knowledge, encouraging adult education, improving production of honey, expanding accessibility of market infrastructure and strengthening supportive institutions.
\end{abstract}

Keywords: Two-stage least square regression: Marketed surplus; Honey.

DOI: $10.7176 / F S Q M / 110-03$

Publication date:September $30^{\text {th }} 2021$

\section{Introduction}

Beekeeping is one of the most important agricultural sub-sectors that enables to utilize natural resources that otherwise would be wasted. It is also believed to play a significant role in the food security of the country through honeybee pollination services of major cultivated crops. It contributes to the national food products through pollination (Melaku et al., 2008). The ecological function of bees has even a higher economic importance than the direct beekeeping products. Bees can benefit 250-300 folds through pollinating particularly pulse seeds and vegetables in raising the production higher than the direct products honey and wax. The global estimate of the value of the service of pollination is US\$ 65-70 billion (Hartman, 2004).

Ethiopia has huge potential for beekeeping because of its endowment with diversity in climate and vegetation resources that potentially favor beekeeping (Workneh and Puskur, 2011). Honey production in the country is most often related with the availability of natural forest and in Ethiopia there is high possibility to produce good quality forest honey (Aravindakshan et al., 2011). As a result, the country is one of the top 10 producers of honey in the world, and it is the largest in Africa (USAID, AGP-AMD, 2012).

Honey production in beekeeping activity is a very long-standing and deep-rooted household activity for the rural communities of Ethiopia. There is an ancient tradition for beekeeping in Ethiopia that stretches back to the millennia of the country's early history. It seems as old as the history of the country and it is an integral part of the life style of the farming communities (Adebabay et al., 2008). According to Ayalew and Gezahegn (1991), no country has a longer tradition of beekeeping than Ethiopia. At the time of king Ezana, around the $3^{\text {rd }}$ century, wax was needed for religious ceremonies, honey for nobility and the social elite making traditional beverages. Despite its long history, beekeeping in Ethiopia is still an undeveloped sector of agriculture. The knowledge and skill of honey production and extraction of Ethiopian farmers is still very traditional (MoARD, 2006).

Beekeeping is a promising farm activity which directly and indirectly contributes to smallholder income and national economy (Belets and Berhanu, 2014). Beekeeping is also important for creating job to landless peoples (Melaku et al., 2013). Honey production of the country is 47,706,101 kg with total number of beehives 5,902,624 traditional, 80,832 intermediate and 205, 873 modern beehives (CSA, 2017). Over 1.5 million farm households are engaged in value chain of honey (MoA, 2013). In addition, a significant number of people are engaged in production and trading of honey at different levels and selling of honey wines (local beverage $T e j$ ) which create job and self-employment opportunities for a large number of citizens. And the sector is contributing 
around USD 2.7 million to the national economy of the country (MoA, 2013).

Oromia regional state is one of the potential areas of honey production which accounts $49 \%$ of the total bee colonies and $48.4 \% \%$ of the total honey production in the country. According to the report of CSA (2017), annually Oromia regional state produces $18,746,087 \mathrm{~kg}$ honey with average production capacity of $6.3 \mathrm{~kg}$ per hive. The study area Jimma zone also shares $4 \%$ of honey produced in the country with the average production capacity of $6 \mathrm{~kg}$ per hive (CSA, 2017). Despite the fact that the quantity of honey product in Oromia takes the major share in the country, the region has been unable to benefit from the sector. Gera woreda is one of the areas that have considerable potential of honey production in Oromia. Though many governmental and nongovernmental organizations have been introducing beekeeping as one of marketable commodities and tried to improve the existing traditional apiculture production system in the woreda, lack of institutional linkages and lack of organized markets for honey still hinder the development of the sector in that area. Besides the major constraints of the sector, particularly in the woreda there are lack of beekeeping knowledge, shortage of trained manpower, shortage of beekeeping equipments, pests and predators, and inadequate research and extension services to support apiculture development program (Melaku et al., 2008).

\section{Material and methods}

2.1Description of the study area

Gera District is one of the 20 districts in Jimma zone of Oromia Regional States. It is bounded by Ginbo SNNP and Seka Chekorsa in the North, Gesha SNNP in the West, Goma in the East and Setema and Sigmo in the South. It is located at about $440 \mathrm{Km}$ from Addis Ababa and $93 \mathrm{Km}$ from Jimma. The total area of the District is about 144,340 ha, of which 3,288 ha are cultivable, 83,919 ha forest covered, 725.5 ha bush land, 900.97 ha grass land, 1,515 ha coffee land (covered by coffee), 7,000ha area covered by mountain and 9,991.11ha settlement area (DOoARD, 2016).

Beekeeping is one of the production systems in the District. Due to conducive agro ecology and farmer's ability generate income from small size of land by beekeeping production. The District has a total population of 147120 where $92 \%$ are male and $8 \%$ are female headed households. From the total population, 50.26\% and 49.74\% are males and females, respectively (BFED, 2016). The livelihood of the population living in the District is directly or indirectly dependent on the agricultural activities. Livestock production and beekeeping are the major sources of income and livelihood of people in the District.

The District receives an annual rainfall ranging from $1800-2080 \mathrm{~mm}$ and the annual mean temperature ranges between 14-24 ${ }^{\circ} \mathrm{C}$. The altitude ranges between 1,500 and 3000 m.a.s.l. Gera District comprises 29 Kebeles of which 2 are urban Kebeles and 27 are rural kebeles (BFED, 2016). The agro-ecological zones of the District are 3.7\%, 50.19\% and 46.11\% lowland, mid highland and high land, respectively. Gera District is known by different agricultural activities like animal fattening, honey production, organic coffee, cereal crop and spice and Gera is endowed with livestock potential of the 252438 cattle, 72940 sheep, 20594 goat, 52584 equine, and 61174 poultry (DOLFRD, 2016). Map of study area is shown under figure 1.

\subsection{Type and source of data}

Both qualitative and quantitative data were collected from primary and secondary data sources. Primary data were collected from sample small holder beekeepers using pre-tested semi- structured interview schedule. Besides, relevant secondary data sources include both zonal and district's office of livestock and fishery resource development, Central Statistical Authority (CSA), published and unpublished reports, and websites were used in addition the survey data.

\subsection{Sample size and sampling procedures}

A two-stage sampling technique was used to select representative honey producers from the study area. Gera district was selected purposively based in the potential it has for honey production in the zone. In the first stage, from kebeles which produce honey, 4 kebeles were randomly selected. In the second stage, 139 samples of household heads were randomly selected from total honey producers in the district 223 and the sample households were drawn randomly from each kebele based on probability proportional to size sampling techniques

\subsection{Methods of data analysis}

Descriptive statistics analysis was used to analyze the data collected from honey producers. Descriptive statistics employed were percentage, frequencies, means, range, and standard deviation in the process of describing households' characteristics. Econometric analysis uses two stage list square (2SLS) model to analyze determinants of honey marketed surplus in the study area because all honey producers participate in the market. Model specification of marketed surplus function is given as the following 
Reduced form: $Y_{1 i}+\pi_{0}+\pi_{1} x_{i}+\pi_{z} z_{i}$

$+\mathrm{v}$

$\mathrm{Y}_{1 \mathrm{i}}$ is endogenous variable (quantity produced of honey); $\mathrm{x}_{\mathrm{i}}$ is vector of exogenous variables; $\mathrm{z}_{\mathrm{i}}$ is a vector of excluded instruments; $\pi$ is the coefficients to be estimated; and $v$ is the errors terms, symmetrically distributed around zero.

Second

Stractural equation: $Y=\beta_{0}+X_{\mathrm{k}}^{r} \quad \beta_{1}+\delta \mathrm{Y}_{1}+\mathrm{U}$

$\mathrm{Y}$ is a vector of quantity of honey supplied to market, $X^{f}$ is exogenous variable that is assumed to affect honey marketed surplus, $\mathbf{Y}_{1}$ is a vector of endogenous variables, $\beta_{0} \beta_{1}$ and $\delta$ are a vector of parameters to be estimated, and $\mathrm{U}$ is a vector of disturbance terms. Honey marketed surplus is continuous dependent variable used in the two-stage list square model. It is measured in kilogram and represents the actual honey supplied to market by farm households in a year 2016/17. The summary of independent variables used in this model are presented below in table 2

\section{Results and discussions}

3.1. Demographic and socio economics characteristics

According to the study result, out of the total sampled households in the study area, 88.5 percent were male while the remaining 11.5 percent were female headed households. This conforms to the common thinking that honey production is men's job due to the biting and absconding or swarming nature of honeybee colonies. Concerning the marital status of the household heads $(89.9 \%)$ were married with only 0.7 percent widowed and 9.4percent were single (Table 3). As indicated in Table 3, Educational level of the household head can influence how he or she views the new technologies and new ways of doing business. It can affect technology adoption decision. Educational level of the sample household heads in the study area ranges from illiteracy to secondary levels. The proportion of household heads that were illiterate was 33\%, those who were at primary; junior and secondary educational levels were $4 \%, 60 \%$ and $3 \%$ respectively.

The overall mean age of the respondents was 39.9 years with standard deviation of 11.3. As table 4 indicated that the average family size of the sampled respondents was 5.3 persons with standard deviation of 2.5. The overall average land holding size of the respondent was 2.8 hectare with standard deviation of 2.3.

Total number of livestock holding of the households measured in Tropical Livestock Unit (TLU). Livestock are farmer's important sources of income, crop cultivation and transportation of produces. As indicated in Table 4, average livestock holding was $6.8 \mathrm{TLU}$ and the standard deviation was 5.4. The average amount of honey marketed per sample household was $412 \mathrm{~kg}$ and the standard deviation was 321. Distance from produce's house to nearest market was also the factor which was expected to determine producer's marketed surplus. As observed from Table 4, the average distance needed for producers to travel to nearest market place was 6.4 kilometer with standard deviation of 4 .

Accounting for children below 14 and elders of above 64 years as dependents, the dependency ratio was calculated. The survey result indicated that the average dependency ratio for households of $72.7 \%$ in Gera District implying that every 100 people within the economically active population groups supported not only themselves but also additional $72.7 \%$ economically dependent persons with all necessities.

Access to Services

Out of the total respondents of honey producing sample households, about $81.3 \%$ have contacted extension services providers. Only $18.7 \%$ of the farmers reported that they had no access to extension service regarding honey production. The extension services providers were office of livestock and fishery resource development experts, DAs, NGO and innovative farmers. The extension services provided were about honey production, input use, harvesting and post-harvest handling.

From the survey result access to market information shows that there is no system in place for systematically collecting, analyzing and disseminating information relevant to the needs of different actors. However, about $56.1 \%$ of sampled farmers had access to market information from different sources and $43.9 \%$ had no access to market information. Finance is the crucial element starting from purchase of input up to the marketing of the product. The survey result showed that $73.4 \%$ of the sample households reported as they have credit access for honey production in the study area. The main objectives of the credit were to purchase honey production input.

Input and Honey Production

The respondents mentioned a wide range of accessories. In the study area inputs used in the process of honey production includes bee colony, beehive, supplementary feed, sanitation materials (like ash and burn oil), honey container and protective wears. It was learnt during the survey that, apart from the known basic hive tools many of the materials are either non-existent or kept by quite few number of respondents. Particularly, the honey extractor was reserved at the center of the kebele for demonstration purpose. Because its potential was low as compared with amount of honey produced in each kebele. 
Honey is harvested in the study area from January through March and from April to June (peak periods) every year. Considering the whole sample, most farmers $(29.3 \%)$ owned 2140 Traditional beehives, $22.7 \%$ owned $41-60,14.7 \%$ owned less than $20,12 \%$ owned $81-100,10.7 \%$ owned $61-80$ and only $10.7 \%$ owned traditional beehives around 100-400 indicating beekeeping is practiced in small scale in the District.

Out of the sampled households only $46.8 \%$ adopted modern beehives. From the total number of beehives owned by the sampled households, around $79.7 \%$ is traditional and the remaining $20.3 \%$ is improved showing that the majority of the households are engaged in traditional beekeeping.

Among those who use traditional beehive, $56.8 \%$ of them harvest honey once in a year. Similarly, $29.2 \%$ of sampled households use modern hive and harvest once per year. As table 7 indicated that $35.1 \%$ and $61.6 \%$ of sample households those who use traditional beehive and improved beehive responded that they harvest two times in a year. From the total sampled households who use traditional beehive and modern beehive $8.1 \%$ and $9.2 \%$ of households reported that they harvest three times in year.

It was investigated from the survey that harvesting of honey twice a year is a common practice in the study area (Table 7). It was also reported that while harvesting of honey, farmers leave some part of it in the beehive and any production obtained in the non-pick periods of the year would also be left as supplementary food for the colony to strengthen it for the next harvest.

Honey yield was markedly different for the traditional and modern hives. On average, it was about 9.6 $\mathrm{kg} /$ hive and $34.7 \mathrm{~kg} /$ hive from the traditional and modern hives, respectively (Table 8). As compared to the national average yield of honey per hive ( $\mathrm{kg} /$ hive), 7.3, 25.2, and 13.3 for traditional, transitional and modern beehives, respectively (CSA, 2017), the District has good potential of honey production. Determinants of Honey Marketed Surplus

Analyses of determinants affecting volume of honey supply were found to be important to identify factors constraining honey supply to market. Prior to fitting multiple linear regressions, the hypothesized explanatory variables were checked for the existence of multicolliniarity, heteroscedasticity and endogeniety problem. VIF was employed to test the existence of multicolliniarity among explanatory variables and the result showed all VIF values are less than 10. This indicates absence of serious multicolliniarity problem among independent variables. Robust OLS analysis with heteroscedasticity consistent covariance matrix was estimated. Testing for endogeniety of quantity produced of honey was carried out in the model using both Hausman test and DurbinWu-Hausman (DWH) test and endogeniety problem was found.

Hausman test result indicated that, the predicted quantity produced of honey was statistically significant with $(p=0.0041)$ when included as additional explanatory variable in structural model which implies hypothesized quantity produced of honey variable is endogenous due to the fact that it is correlated with error term. Durbin Wu-Hausman test results also show that the null hypothesis of exogeneity of the quantity produced honey was rejected at $1 \%$ probability level $\left(\chi_{2}^{2}=8.91967\right.$ and P-value $\left.=0.0028\right)$ using estat endogenous STATA command after ivregress. Therefore, two stages least square (2SLS) method was used to address the endogeniety problem.

Two stages least square (2SLS) method was used to identify determinants of honey marketed surplus by honey producers in the study area. In the first stage of 2SLS method, regressions was run and analyzed using thirteen explanatory variables including tropical livestock unit and number of beehive and the result shows that, cash income other than beekeeping, tropical livestock unit and number of beehive affected significantly quantity produced of honey. Amount of tropical livestock unit and number of beehives were used as instruments for honey marketed surplus.

In second stage of 2 SLS from hypothesized twelve explanatory variables, seven variables i.e., quantity produced, family size, distance from nearest market, beekeeping experience, frequency of extension contact, type of bee hive used and sex of the household head significantly influenced volume of sales of honey. As depicted in Table 9 the model was statistically significant at $1 \%$ probability level indicating the goodness of fit of the model to explain the relationships of the hypothesized variables. Coefficient of multiple determinations $\left(\mathrm{R}^{2}\right)$ was used to check goodness of fit for the regression model. Hence, $\mathrm{R}$ indicates that 87.02 percent of the variation in the quantity of honey supplied to market was explained by the variables included in the model. The explanation on the effect of the significant explanatory variables is discussed below.

Quantity of honey produced in kilogram in 2016/17 production season in the study area. As hypothesized quantity of honey produced was positively related with honey marketed surplus and significantly at $1 \%$ probability level. The value of the coefficient for quantity of honey produced implies that an increase in quantity of honey produced by one kilogram resulted in an increase in volume of sales honey by 0.37 kilograms, keeping other factors constant. The higher the quantity of honey produced the greater the tendency for the farmers to supply honey to market.

Sex of the household head was found to be positively and significantly influenced on honey supply to market at 5\% level of significance. The positive sign shows being a male head of a household significantly increase honey quantity supplied to market by 106.4 kilogram as compared to that of female-headed households, 
keeping other variables constant. The reason behind male headed households supplied more honey to market than female headed households, may be females can take higher care than males about households' consumption by saving from produce to feed household; this can reduce the quantity to be sold.

Family size affected supply of honey to market negatively and significantly at $1 \%$ level of significance. The negative effect of the variable shows that as the number of household members increased more part of honey produce may be allocated for household consumption. As the member of household increased by one, volume of honey supplied to market is decreased by 27.89 kilogram.

Distance to the nearest market affected honey marketed surplus negatively and significantly at $1 \%$ significance level as expected. The result showed that as the distance from the nearest market increased by one kilometer, the quantity of honey supplied to market decreased by 19.089 kilogram, holding all other variables constant. This is because as the distance from the market increases, transportation cost also increases to transport honey which in turn may decreases the marketed surplus. The longer distance of the market, the higher would be the transportation charges, increased walking kilometer, and increased other marketing costs.

Beekeeping experience of households affected honey marketed surplus positively and significantly at less than $1 \%$ significance level. Thus, the result implied that, as producers experience increase by one year, the honey supplied to market increased by 47.786 kilogram, keeping others factors constant. This means that the producers with more experience in honey production and marketing have higher ability to sell more honey produces in the market than less experienced because they have more marketing network and information.

Frequency of extension contact affected supply of honey to market positively and significantly at $1 \%$ level of significance. The positive and significant effect may be due to the reason that beekeepers who get more knowledge during contact with extension agent for honey production particularly about modern honey production, harvesting, storing and handling methods contribute to increasing the amount of honey production. As increases in Extension contact by one day resulted in an increase in volume of sales of honey by 9.584 kilogram, keeping other factors constant.

Type of beehive used to produce honey affected supply of honey to market positively and significantly at $10 \%$ level of significance. This can be explained as farmers possessing modern beehives produce better volume than those who use the traditional one and the more, they produce, the more they tend to supply to the market.

\section{Conclusions and recommendations}

The aim of this study was to identify the determinants of honey marketed surplus among smallholder honey producers. The primary data were collected from individual interview using semi-structured questionnaire from 139 randomly selected honey producer households. Secondary data were obtained from different sources like zonal and district's office of livestock and fishery resource development, central statistics authority (CSA), published and unpublished reports and websites. Both descriptive statistics and econometric analysis were used for data analyze. The descriptive statistics measures like mean, percentage, standard deviation were used in characterizing demographics and socio-economic access to services, input and honey production. 2SLS model used to identify factors affecting honey marketed surplus and the result indicated that quantity of honey produced, sex of the household head, beekeeping experience, type of beehive used, frequency of extension contact positively and significantly affect honey marketed except family size and distance to the nearest market. Based on the result the study suggested that increasing quantity produced of honey in the area by promoting modern beekeeping equipment, providing training on improved honey production skill and processing their hive produce, technical support to beekeepers in beekeeping, increasing follow up. Improving rural infrastructure and developing market infrastructure in the form of establishing producer collection points across rural areas would assist poor beekeepers for faster delivery of beehive products. To increase honey marketed surplus there is a need to focus female headed households by facilitate and giving priority for increasing marketed surplus. There is a need of family planning intervention since larger family size requires larger amounts of honey for consumption, thus reducing marketed surplus.

\section{Competing interest}

The authors declare no competing interests.

\section{References}

Adebabay, K.et al. (2008). Beekeeping in Amhara region: Amhara Regional Agricultural Research Institute (ARARI). EIAR (Ethiopian Institute of Agricultural Research). Debre Zeit, Ethiopia. p.1-36.

Aravindakshan, S.et al.(2011). Exploring the potential of non-timber forest products: the case of Ethiopian honey export to Denmark submitted to the University of Copenhagen.

Ayalew, K. and Gezahegn, T. (1991). Suitability and classification of apiculture potential area: Ministry of agriculture. Addis Ababa, Ethiopia. p.56-57.

Belets, G. and Berhanu, G. (2014). Adoption of Improved Box Hive Technology: Analysis of smallholder 
farmers in Northern Ethiopia. Journal of Agricultural Economics and Extension2, p. 77-82.

BFED (Bureau of Finance and Economic Development). (2016). Gera district's Bureau of finance and economic development.

CSA (Central Statistical Agency), Agricultural Sample Survey. (2016/17). Volume II. Report on livestock and livestock characteristics (private peasant holdings). CSA, Addis Ababa, Ethiopia.

DOLFRD (District Livestock and Fishery Resource Development). 2016. Gera district's Bureau of Livestock and Fishery Resource Development.

Melaku, G. (2008). Approaches, Methods and Process for Innovative Apiculture Development: Experiences from Ada'a-Liben Woreda, Oromia Regional State, Ethiopia. Improving Productivity and Market Success (IPMS) of Ethiopian Farmers project Working Paper. ILRI (International Livestock Research Institute), Nairobi, Kenya.48p.

Melaku, B. (2013). Identifying beekeepers' adaptation strategies in response to climate change in Tigray, Ethiopia. Journal of Agricultural Research 2, p.155 - 159.

MoA (Ministry of Agriculture). (2013). The $6^{\text {th }}$ national monitoring plan for residues in honey Addis Abeba.

MoARD (Ministry of Agriculture and Rural Development). (2006). Annual reports series 2005, 2006.MOARD, Addis Ababa, Ethiopia.

USAID (United States Agency for International Development). (2012). Agricultural growth programagribusiness and market development (AGP-AMDe) Project. Submitted by ACDI/VOCA to contracting officer's representative Tewodros Yeshiwork, USAID Ethiopia.

Workneh, A. and Puskur, R. (2011). Beekeeping sub sector challenges and constraints in Atsbi Wemberta district of Eastern Zone, Tigray Region, Ethiopia. Journal of Agricultural Extension and Rural Development Vol. 3(1), pp. 8-12 http://academicjournals.org/JAERD ISSN- 2141 -2154

\section{Appendixes}

Tables

Table 1: Sample distribution of honey producers in selected kebele

\begin{tabular}{llclc}
\hline No. & Kebeles & Total number of honey producers & Proportion & Number of sampled households \\
\hline 1 & Genji chela & 70 & 0.317 & 44 \\
2 & Gera naso & 65 & 0.295 & 41 \\
3 & Kecho underacha & 40 & 0.18 & 25 \\
4 & Sedi loya & 48 & 0.209 & 29 \\
5 & Total & 223 & & 139 \\
\hline
\end{tabular}

Source: Gera District office of livestock and fishery resource development 2017.

Table 2: Description of dependent and independent variables used in 2sls models

\begin{tabular}{|c|c|c|}
\hline Variable & Measurement & Expected effect on outcome \\
\hline Sex of the Household Head & Dummy $(0=$ male, $1=$ female $)$ & $+\mathrm{ve}$ \\
\hline Family Size & Continuous (number of families & $-\mathrm{ve}$ \\
\hline Educational level of the Household Head & Continuous (grade level) & $+\mathrm{ve}$ \\
\hline Distance to Nearest Market & Continuous $(\mathrm{km})$ & -ve \\
\hline Quantity of honey produced & Continuous (Kg) & + ve \\
\hline Market Information & Dummy $(0=$ no $1=$ yes $)$ & $+\mathrm{ve}$ \\
\hline Credit Access to Honey Production & Dummy $(0=$ no $1=$ yes $)$ & $+\mathrm{ve}$ \\
\hline Extension service & Continuous (number of contact) & + ve \\
\hline Cash Income other than Beekeeping(log) & Continuous (number in birr) & $+\mathrm{ve}$ \\
\hline Years in Beekeeping & Continuous (number of years) & + ve \\
\hline Type of beehive used & $\begin{array}{l}\text { Dummy } \\
0=\text { otherwise })\end{array} \quad(1=$ modern $\quad$ hive & + ve \\
\hline Market price(log) & Continuous (number in birr) & $+\mathrm{ve}$ \\
\hline
\end{tabular}


Table 3. Demographic characteristics of sample household heads (dummy and categorical variables)

\begin{tabular}{lll}
\hline Variable & Frequency & Percentage \% \\
\hline Sex & 16 & \\
Female & 123 & 11.5 \\
Male & & 88.5 \\
Educational status & 46 & 33 \\
Illiterate & 6 & 4 \\
Primary (1-4) & 83 & 60 \\
Junior (5-8) & 4 & 3 \\
Secondary (9-10) & & \\
Marital status & 125 & 89.9 \\
Married & 3 & 9.4 \\
Single & 1 & 0.7 \\
Windowed & &
\end{tabular}

Source: Survey result, 2017

Table4: Demographic and socio-economic characteristics of sample household heads (continues variables)

\begin{tabular}{lll}
\hline Variable & Mean & Standard deviation \\
\hline Age of the household head & 39.9 & 11.3 \\
Year in beekeeping & 9.6 & 7.9 \\
Total number of family size & 5.3 & 2.5 \\
Size of land holding & 2.8 & 2.3 \\
Distance to nearest market & 6.4 & 4 \\
Quantity supplied to market(kg) & 412 & 321 \\
Tropical livestock unit (TLU) & 6.8 & 5.4 \\
\hline
\end{tabular}

Source: Survey result, 2017

Table 5. Age category and dependency ratio

\begin{tabular}{llll}
\hline Age category & Frequency & Percent & Dependency ratio \\
\hline $1-14$ & 251 & 40.8 & $72.7 \%$ \\
$15-64$ & 356 & 57.9 & \\
364 & 8 & 1.3 & \\
Total & 615 & 100 & \\
\hline
\end{tabular}

Source: Survey result, 2017

Table 6. Access to service of sampled household

\begin{tabular}{lll}
\hline Description & Frequency & Percent \\
\hline Frequency of extension contact & & \\
No extension contact & 26 & 18.7 \\
Ones in month & 19 & 13.7 \\
Twice in month & 35 & 25.2 \\
Four times in month & 59 & 42.4 \\
Access to market information & & \\
Yes & 78 & 56.1 \\
No & 61 & 43.9 \\
Access to credit & & \\
Yes & 102 & 73.4 \\
No & 37 & 26.6 \\
\hline
\end{tabular}

Source: Survey result, 2017 
Table 7: Frequency of harvest and number of beehives

\begin{tabular}{lll}
\hline Frequency & of & Type of beehive \\
\cline { 2 - 3 } harvest & Traditional beehive \% & Improved beehive \% \\
& $\mathrm{N}=4684$ & $\mathrm{~N}=1192$ \\
\cline { 2 - 3 } 1 & 56.8 & 29.2 \\
2 & 35.1 & 61.6 \\
3 & 8.1 & 9.2 \\
\hline
\end{tabular}

$\mathrm{N}$ = number of beehives; Source: Survey result, 2017

Table 8 . Volume of honey production per beehive

\begin{tabular}{lllll}
\hline Type of beehive & Mean(kg/hive) & Standard deviation & Minimum & Maximum \\
\hline Traditional & 9.6 & 3.1 & 5 & 10 \\
Modern & 34.7 & 6.7 & 30 & 42 \\
\hline
\end{tabular}

Source: Survey result, 2017

Table 9. Determinants of amount of honey supplied to market (2SLS estimates)

\begin{tabular}{llll}
\hline Variables & Coefficients & Robust Std. Err. & t-value \\
\hline Constant & $-1159.818^{* * *}$ & 401.686 & -2.89 \\
Quantity produced of honey & $0.370^{* * *}$ & 0.03 & 12.47 \\
Sex of the house hold head & $106.404^{* *}$ & 52.861 & 2.01 \\
Educational level of the household head & 7.481 & 7.792 & 0.96 \\
Cash income other than beekeeping(log) & -16.808 & 14.993 & -1.12 \\
Year in beekeeping & $47.786^{* * *}$ & 9.792 & 4.88 \\
Type of beehive used & $76.614^{*}$ & 41.492 & 1.85 \\
Lagged price(log) & 238.572 & 199.523 & 1.20 \\
Extension contact for honey production & $9.584 * * *$ & 2.223 & 4.31 \\
Access to honey market information & 7.298 & 45.602 & 0.16 \\
Distance to nearest market & $-19.089 * * *$ & 5.242 & -3.64 \\
Family size of the household & $-27.889 * * *$ & 9.177 & -3.04 \\
Access to credit & -12.401 & 35.729 & -0.35 \\
\hline
\end{tabular}

Note: Dependent variable is quantity of honey supplied to market in kilogram in 2016/2017.

Number of obs $=139$, Prob $>$ chi2 $=0.000$

$\mathrm{R}$-squared $=0.87, * * *, * *$ and $*$ significant at $1 \%, 5 \%$ and $10 \%$ respectively

Source: Own computation from survey result, 2017.

Figures

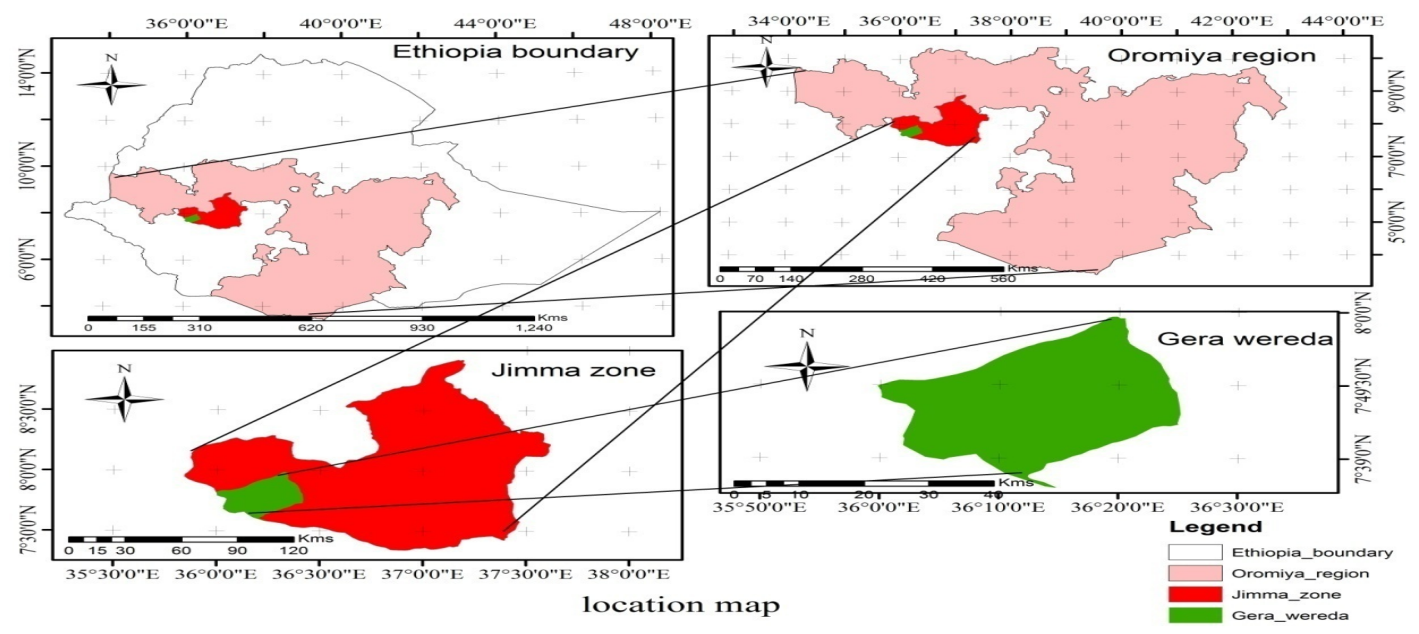

Figure1. Geographical location of the study area

Source: Adapted from Ethiopia map 